\title{
The Experiences of Women Professionals in the Film Industry in Turkey: A Gender-Based Study
}

\author{
Hasan Gürkan \\ Istanbul Arel University (Turkey) \\ E-mail: gur.hasan@gmail.com
}

\begin{abstract}
The article is based on 20 in-depth interviews with women professionals conducted for a more comprehensive study focusing on gender roles within the film and television industry in Turkey. This study examines the career possibilities for women, the experience of being a woman working in television and cinema, and the working environment, including work-life balance issues, experiences of discrimination and experiences of sexism. The hypothesis of this study is that film industry is male-dominated, and women have to struggle to be able to prove themselves in this industry in the 21st century in Turkey, where the position of women is made even more difficult by the gender role codes and the structure of Turkish society.
\end{abstract}

Keywords: film industry, gender, women, gender role, Turkey.

The World Economic Forum assessed the gender gap in 134 countries by measuring the extent to which women have achieved equality with men in four areas: economic participation and opportunity, educational attainment, health and survival, and political empowerment (Hausmann et al. 2010, 6-7). According to the Forum's report in 2010, Turkey is ranked the 126th. This shows that gender inequality is very high, Turkey usually scores poorly in rankings of gender balance in both politics and economics. The changes in approach towards women in Turkey began to emerge with the declaration of the republic. In the first years of the Republic, Mustafa Kemal Atatürk acknowledged the importance of women in both social and business life. In a speech he made in Izmir in 1923, Atatürk emphasized the importance of women in social life, saying: "everything we see in the world is the work of women" (Doğramacı 1992, 79). Turkish women won the right to vote and to be elected in 1933 with their legal rights granted by civil law. In the first elections held in 1937, there were 18 female members actively working in the Parliament. This result corresponds to 4.5 percent of the parliament of that 
time (Doğramacı, 1992, 81). This became the most important indicator that women have equal rights with men at work as well as at every level of society.

However, media industry, which has an intensely female employee basis, has become one of the industries in which discrimination is most experienced. Doğramacı (1992) states that private broadcasting in Turkey - especially in the last twenty years - has provided new opportunities for women. In 2015, according to the report of the Turkish Statistical Institute (www.tuik.gov.tr), women made up 25.9 percent of Turkey's total labour force. There are no reliable records about the number of people employed in the film industry in Turkey which could clearly show the statistical differences between males and females. Nevertheless, according to the report by the Department of General Directorate on the Status and Problems of Women, Republic of Turkey Prime Ministry (2004), with the increase in the number of private media companies during the last decade, the number of working women, particularly in the film industry, has increased. Yet, the proportion of women in managerial positions is still at insignificant levels. Gender-desegregated data on employees in the different sectors of the media is scarce. Therefore, reference can only be made to some fragmented sources of information. For example, women held only 1,873 of the 11,322 yellow ID cards given to journalists in June 2000; in the autonomous Turkish Radio and Television Institution (TRT), women hold 2,030 of the 8,180 personnel, and 116 of the 214 managerial posts. In the latter, women are concentrated mainly in middle management and they make up only $1 \%$ of the high-level management posts. The annual ratio of women-oriented programmes on TRT television channels is $6.9 \%$, and on the radio channels, it is $15-17 \%$ (General Directorate on the Status and Problems of Women, 2004, 4). Tanrı̈̈ver $(2000,185)$ states women used to be only in front of the camera, as actresses, until the 1980s. Later, however, although the cinema sector was affected by the economic crisis, women started to enter this sphere as well.

\section{The Aim of the Study}

The present study discusses the relationship between gender roles and the positions of women professionals in Turkish film industry based on the following research questions: Is film industry a male-dominated sector in Turkey? Do women have to struggle to be able to prove themselves in this industry? Is this industry promising for women particularly due to the gender roles codes and the structure of Turkish society? 
In line with the aim of the study, an in-depth qualitative method ${ }^{1}$ was selected and semi-structured interviews were undertaken with 20 women professionals in the film industry. The 20 participants were asked open-ended questions about themselves and the film industry they have been working in. All participants were required to have at least four years of work experience in film industry. It was important that participants come from Turkey's largest cities because cultural texture and its reflection on gender roles in big and small cities in Turkey is different. Participants belong to the age group of 25 to 40 years old because we assumed that this age range adequately reflects the cultural codes of contemporary Turkey. Participants were required to have at least a bachelor's degree because the relationship between education level and being individual was also considered. The interviews were conducted face-to-face by the researcher. The interviews were undertaken between 18 February and 22 September 2016. The questions were related to gender roles and their outcomes for women professionals as well as related to the general overview of film industry. The questions of the in-depth qualitative interview were the following:

1. How long have you been working in this sector? What positions have you held?

2. Is cinema/television sector male-dominated or woman-dominated?

3. How does society perceive your job?

4. Is there gender discrimination in film industry?

5. Have you ever been molested?

6. Are there any advantages for a woman in this industry? If so, please explain.

7. Are there any disadvantages for a woman in this industry? If so, please explain.

8. How would you define film industry in Turkey in three sentences or less?

9. Do you see that film industry is a good field of work for women? If so/not, why?

10. What position is better for a woman in cinema-television sector in Turkey? Why?

1 An in-depth interview is a qualitative research technique that involves conducting intensive individual interviews with a small number of respondents to explore their perspectives on a particular idea, programme, or situation. The in-depth interview is useful when researchers want detailed information about a person's thoughts and behaviors or want to explore new issues in depth. Interviews are often used to provide context to other data (such as outcome data), offering a complete picture of what happened in the program and why (Boyce et al. 2006, 3). 


\section{Theoretical Background and Gendered Segregation in Turkey}

There is an interaction between gender and social structure. Gender roles are affected by the social and cultural codes of the society in which they are produced, but they also simultaneously play a role in shaping these codes. "Gender" is a different concept from "sex," which basically refers to biological differences between men and women. While sex points to physiologic differences, gender encompasses a cultural structure, which embodies the social and cultural meanings of and expectations of men and women (Dökmen 2004; Rice 1996; Lips 1998). According to Unger and Crawford (1993) gender is determined by psychosocial properties that categorize an individual as man or woman (see also Erus and Gürkan 2012, 207). Men and women are different in social, cultural, economic and political aspects, and based on such differences (see Gentile 1993; Fausto-Sterling 2012; and Bem 1983), this separation is not neutral. It is structured in the social organizations such as ideology, family, economy, law, and politics that organize the daily life of individuals. It defines roles for men and women in line with the dominant ideology. Gender roles are strengthened through institutions such as family, school, and media, and they are based on hegemony and repetition. In sociology, the notions of gender and sex have been discussed, among others, by Ann Oakley, who examines the unequal division among men and women based on social structure (1972). Social roles produce social expectations in connection with social statutes (Marshall 1999, 624). Gayle Rubin (1975) discusses gender as a sex-gender system, in which the social gender is described as enhancing the idea of a biological gender. It implies that the gender image for both sexes is being distorted due to gender being socially constructed. In gender theory, there is also the discussion of the power aspect being built into the gender system: the male is the norm, the female is the follower (Fausto-Sterling 1993).

The notion of gender roles is used for reflecting on gender stereotypes or differences, which are constructed by society. Sex roles include social expectations, which limit the activities experienced by men and women. Social expectations cause pressure on people, who have to follow the rules (Kaypakoğlu 2004, 20). After babies are assigned as girls or boys by the society, they start to learn cultural meanings. The cultural meanings of sex are seen as gender roles. Gender role is a set of expectations which is described by the society and related to sex. During this socializing process girls and boys learn which objects, games, jobs, and events are favourable for them (Dökmen 2004, 16). 
Sex roles can be described as cultural expectations, which determine how men and women must act in their daily lives in a society (Zanden 1990, 228). Sex roles contain the ideas of men providing food and women providing child-care. This can be considered as a division of labour among men and women in the public area. Working in the public area is rewarded with power, money, and prestige, but on the other hand, working in the private area is seen as worthless and isolated (Zanden 1989, 227). As Oakley $(1972,204)$ states, humans created the concept of gender, thus gender is associated with a social construction. According to Blackstone (2003, 336-337), the social construction of gender is determined by the fact that individuals, groups, and societies ascribe particular traits, statuses, or values to individuals purely because of their sex, yet these ascriptions differ across societies and cultures, and over time within the same society. Gender roles are the roles that men and women are expected to occupy based on their sex. Blackstone $(2003,337)$ states that many Western societies have believed that women are more nurturing than men. Therefore, the traditional view of the feminine gender role defines that women should perform in ways which are nurturing. On the other hand, men are assumed by traditional views of gender roles to be rulers/leaders/ controllers, etc. While these views continue to dominate society, alternative views on traditional acceptances about gender roles have been achieved. In the situations in which roles are not clearly described, male leaders are more prescriptive and more mission-oriented, while females are more democratic and considering the team spirit (Mayers 1996, 199). Mayer's claim is relevant to gender roles.

Sex roles include the acceptance of inequalities. Social roles and especially sex roles shape and reflect the structural and cultural characteristics of society (Kammeyer, Ritzer, and Yetman 1997, 34). On the one hand, women produce an important part of economic growth in Turkey. On the other hand, women's duties in daily household work, in child-care, in the education of children, as well as childbirth are obstacles for women to enter working life. Regarding the type of work that they do, women are concentrated in certain sectors and businesses. Women have to choose "women's jobs" in their working lives. Sectors and businesses determine women's places in professional life.

\section{Findings}

Female-dominated areas in film industry are as follows: assistant to producer, assistant director, costume designer, editor, guest coordinator. The number of women is higher than that of men in the departments such as make-up, costume 
and assistant. It is possible to encounter this situation not only in Turkey but in European countries as well. For example, the data obtained from the reports of the European Women's Audiovisual Network (EWA) (European Women's Audiovisual Network Reports 2006-2013, 20-21) is quite striking: most of the participants in these reports believe that there is gender inequality in the sector. While the countries with the highest inequality are Germany, United Kingdom, and Austria; Croatia is perceived as the country with the lowest inequality. According to the EWA report, likewise, the proportion of female directors in European countries is as low as in Turkey, except for Switzerland. It is not wrong to say that this is related to the gender codes of the Turkish society. While there are (almost) no women in the duties of the commander, women are (only) dominant in costume and make-up designer as well as in assistant positions.

\section{a) It is a male-dominated sector}

In Turkey, a patriarchal society, males dominate film industry, just as other industries. According to the report of Turkish Statistical Institute (www.tuik.gov. tr), in 2015, while employment of men was $65 \%$, the employment of women was $27.5 \%$. All interviewed women remark that film industry is male-dominated in Turkey. This is relevant to gender. As Turkey is a patriarchal society, men come before women, particularly in professional life. Men are the heads of the households and women are good wives, good mothers. From this point of view, while many of the working areas in film industry - such as technics, directing, etc. - are filled by men, other areas - such as editing, costumes, make-up, art direction - are more open for women because they do not need physical strength. The above stated are corroborated by interviewees 1, 11, 18, 19, and 20, who state that: "this sector is male-dominated, but men dominate all sectors in Turkey." Moreover, interviewees 2, 4, 7, 8, 9, 13, and 14 explain that "there are always more men than women in film sets. The technical crew is almost $100 \%$ men. Women usually work in the departments such as production, direction, editing, make-up and cast departments. There are more women in costume department than men." As it can be seen, tasks that require physical strength are performed by men, while tasks that require aesthetic sense are done by women. 


\section{b) Sex Discrimination and Sexual Harassment}

There is a strong connection between sex discrimination, sexual harassment, and gender roles. Common examples of sexual harassment include unwanted touching, the invasion of personal space, making sexual comments about a person's body or attire, and telling sexual jokes (Uggen and Blackstone 2004). Gutek (1989) claims that women's sexualities are more perceived than men's sexualities, that woman's sexualities are at the forefront of increasing sexual harassment. On the other hand, the sexuality of men at the workplace is not very prominent. Men tell some sexual jokes and use offending language regarding to women. Cleveland and Kerst (1993) demonstrated the links between institutional, personal, or interpersonal-strength traits to sexual harassment. Social and institutional power sources form the basis for working conditions that can increase or prevent sexual harassment. Women who work in male-dominated occupations such as film industry, and who are young, single, or divorced are the most likely to experience sexual harassment (Jackson and Newman 2004). Besides this, gender discrimination, which causes women to be deprived of their full and free participation in daily-life activities involves various issues such as non participation in decision-making mechanisms, not benefiting from public opportunities, living in unhealthy conditions, encountering obstacles in working life, being harassed at the workplace or experiencing unfairness. While many of the interviewees state that "I have not been harassed with hands, but I have been harassed with behaviour and phone-calls," the other interviewees underline their experiences as follows: "men wrapped their hands around our necks and started to talk about the so-called works on the first day of the set... I was not able to be angry, just ashamed and surprised... But if we react, they can do this only once, or a few times verbally." These statements highlight the relationship between sexual harassment and sex. Moreover, gender discrimination is about the lack of basic services for women, about having unequal conditions compared to men, about the violence, the politics and the low representation of women in working life. Regarding sexual discrimination, many of the interviewees state that "there is discrimination. There are many physical differences between women and men. In the set, we have no chance to do something else during working hours. Unfortunately, it is very hard to explain to the opposite-sex some special days such as period days." The following statement is also dramatic: "as a woman, when I started to work as a director, first I had to prove my technical knowledge to the technical crew to make them get work done. Because if you are a woman 
director, all male-dominated technical crew may think some thoughts such as "well, just a woman," and they may try to lie to you. This male-dominated crew respects male directors all the time. Male directors do not have to make an effort to establish authority." It is possible to say that the reasons why women are not accepted as directors are related to the patterns of social roles that women should undertake. A director manages and orders, but a woman cannot rule and order.

\section{c) Is the Best Job for a Woman Being a Teacher?}

Sex segregation in occupations continues for several reasons. Firstly, cultural beliefs about what is an "appropriate" job for a man or a woman exist. Using in-depth interviews, it is possible to identify patterns of sex segregation. According to the interviewed women and their social environment, it can be discussed what is considered suitable for women as a job in society. Secondly, opportunity structures for men and women differ. Women often find that their opportunities for career advancement are adversely affected after returning from child-rearing leave. Finally, there is evidence that working mothers pay a price for motherhood. Child-care is the responsibility of women even if they work in Turkey. Sex stereotypes, just as other stereotypes, reflect the observations related to what people do in their daily lives. If a set of people are monitored as they are undertaking activities, it is believed that these people have essential abilities and personality characteristics for these activities (Dökmen 2004, 84). Moreover, when we look at the employment rates in 2015, it can be seen that $70.1 \%$ of men are employed, compared to $30.6 \%$ of women (tuikapp.tuik.gov.tr). In light of this information, the interviewed women underline that working in the film industry is hard and society perceives this job as not being the best for women in countries such as Turkey. These comments summarize the idea very well: "if your motto is 'the best job for a woman is being a teacher,' this job never suits you. You will never be able to be an ideal mother, wife, friend, daughter, cousin because of its difficulties and irregular working conditions. You are tired, busy; you cannot even manage to go to the cinema at all. You will have to work when everyone is on holiday; when they work, you will have to work again. The fear to this question is with you all the time: 'When I go back to my job from maternity leave, can I stay in my job or do I have to find a new job?"' It is possible to point out from all of these comments that there are many problems in women's working life. According to Kazgan (1979), women do not have such a long history if considering their professional life in Turkey. He mentions that 
women's professional life is related to their educational background and their marital status. There are no proper job opportunities for undereducated women; they can mostly work in low-paid jobs related to household chores. This claim is supported by the following comment: "this sector is not stunning, especially not for women. For example, while I do my best in my job, the male crew does not respect me. My female identity stays in front of the sets. I have tried to go to the sets without my female identity, but the male crew does not accept it." The other says: "I work in an office; all I do is to produce, to create a meaning. In this sense, working in an office with famous people is stunning for a woman. However, there is no stunning way for a woman because of the difficulties."

\section{d) "I Have a Job, but Not a Family!"}

Being a woman is hard in societies such as Turkey since all women are socialized to prepare them for "being a good mother" and "being a good wife" by their parents and by the other socialization ideological apparatuses such as educational institutions, families, religion, and media. According to Donovan (2000), there is a tradition of idealizing the role of the "housewife" in societies that tend to seclude women. In Turkey, especially before establishing the republic and during the first years of the republic, this view was very strong. ${ }^{2}$ However, after establishing the Republic and during the modernization process of Turkey, women were needed as labour force. In this sense, women started to go out from the private area to the public area by entering business life.

Moreover, Seger $(2003,76)$ mentions that mothers need to balance family and work. Many women, mothers or not, see balance as essential to being healthy and effective. Although it is not unusual to hear from workers in any field that they want less work and more play in their lives, there is a difference in film industry. The interviewees' comments about their jobs and family lives are dramatic. Half of the interviewees state that working in film industry is quite hard, especially for women. "Irregular life conditions affect negatively our families. For example, I was pregnant and I had to work until the mornings under very much stress for a big project in the $4^{\text {th }}$ and $5^{\text {th }}$ period of my pregnancy. I cried many times and I had a nervous breakdown. I could not see my husband's face for many days. Moreover, I had no idea about the fate of my job after going on maternity leave, after having a baby. I started to think, come what may, but I don't feel safe. Not

2 Still, some women are not allowed to work by their husband or their families in some parts of Turkey. 
being able to make plans as a family is one of the worst matters. The answer to this question: Shall we go somewhere two weeks from now? The answer does not exist, because it is not clear which day you have to work two weeks from now. I miss planning summer holidays." As sex roles are prescribed by the society, there is some pressure on people to act accordingly. For example, there is a strong belief in Turkey that married women must do housework. Notably, their mothers, their husbands, their neighbours, and their friends consider them responsible for doing housework. The interviewees made these comments as well: "working hours are so fuzzy. I as a woman may be harassed or be abused. Mobbing is so popular in this sector, and if you are a woman, you definitely could be under psychological pressure." "Working hours are fuzzy and we have to work for many hours. Therefore, we do not have quality time for our families, friends. This is not the right job for women who would like to get married or have a kid." Consequently, women in professional fields must choose between their families and their jobs. Especially in film industry, they are affected by poor working conditions. According to all interviewed women in this study, film industry's working conditions, the workers' rights, and social insurance are terrible.

\section{e) Is the Job Promising (Attractive) for Women?}

According to the Inter-Agency Standing Committee (IASC 2009, 7), gender mainstreaming is the process of assessing the implications for women and men of any planned action, including legislation, policies of the program, in all areas and at all levels. However, it is possible to say that there are difficulties in practice, as can be understood from the answers given by the interviewees. The interviewees say that film industry is not promising for women because of the gender gap in Turkey: "the sector is worse now than when we started. There are severe issues with the payment system, as they try to avoid paying social insurance. However, this is not legal. If we look at the case of Turkey, every sector has problems. I like my job whatever happens, and first of all, I tell these issues to everyone who wants to work in this sector. If they want to, despite all these, then they can succeed. Sometimes they may be unhappy because of the stress or tiredness. The most important thing is to be able to say 'it is worth it.' I cannot say something absolutely sure about the future of the sector. Lots of TV series are made, they are useful for both advertisers and the government. Therefore nobody is made redundant, but I cannot know how things will go on." Grassroots movements, such as feminism and women's rights and human rights 
movements have made significant inroads in the fight against gender inequality in general. However, the women given voice in this study think that film industry is not attractive enough for them: "working in film industry is not appropriate for women in Turkey because women have a challenging job in the industry. Unfortunately male opposition against women is really strong and this prevents women's career." On the other hand, the feudal system still exists in Turkish society and in this sector. One of the interviewees sums this up in this way: "I see that all women in our society need to be supported by men to be able to get a prestige in professional life. This is related to feudal society. This reality has been revealed in this industry."

\section{Conclusions}

There is no data on the exact number of female professionals in film industry in Turkey. However, we can assume that the number of female directors, assistant directors, and camera crew is very low in the country. Moreover, film industry in Turkey is not promising for women, and women encounter here many difficulties - such as discrimination, sexual harassment, family problems, etc. Many women experience physical, sexual, psychological pressure and economic discrimination in this industry. Long working hours and bad working conditions have become one of the foremost issues to discuss besides the issue of occupational accidents, and there seems to be no permanent solution to solve these issues.

Based on the interviews, although all the participants have a bachelor's degree in this industry, they cannot advance in their careers. Women can rarely rise in their organization's hierarchy because they encounter some unknown and unforeseen obstacles. This phenomenon is described as the glass ceiling effect (Hymowitz and Schellhardt 1986). According to the Federal Glass Ceiling Commission (1995), this term refers to "artificial barriers to the advancement of women and minorities." These barriers reflect "discrimination [...] a deep line of demarcation between those who prosper and those left behind." In many professions, women cannot break through the glass ceiling to the upper level of management just because they are women. Therefore, the number of women decreases towards the top of the hierarchy. Many popular beliefs regarding women and men support this issue. For example, the idea "women do not have the ability to lead" as opposed to men, who also set the standards for social values and behaviours. Men are seen as appropriate for decision-making roles at all times. This situation is relevant to sex and gender. Öztürk-Akar (2012) and Köse (2013) state that the 
most appropriate profession for women in Turkish society is being a teacher. This also coincides with the comments of the interviewees. When working in the profession they want, that is, working in film industry, the highest position they can raise to is that of assistant director. Since the gender roles referring to women in society are obstacles for women to be able to express themselves in their own professions, we found that the typical patriarchal thoughts still prevail in film industry, which is considered to be far away from traditional values. Therefore, women in film industry work in very difficult conditions and they cannot advance in their profession because of gender-role perceptions - as shown in this study.

All interviewees describe film industry as a male-dominated one. Moreover, $99 \%$ of women working in film industry have experienced sexism, which is a substantial amount indicating the strong connection between sexual harassment and gender roles. The professions in Turkey have horizontal stratification and they are divided into women's jobs and men's jobs. As Kocacik and Gökkaya (2005, 207-212) show, women's jobs consist of low-status, low-wage, temporary, precarious jobs, which require no qualifications, while male jobs require authority and responsibility and are highly paid, continuous and secure. Most women are also exposed to psychological harassment, or mobbing, at the workplace, and they are put in the second place in many areas and often have to handle the obstacles in the way of their professional life due to the necessities and responsibilities of and in their family life.

The interviewees also underline that working in film industry as a woman is difficult and this profession is not suitable for women. This is attributed to cultural beliefs and gender roles. Women working in film industry may encounter many difficulties in society. It is possible to state that the general public does not consider film industry a real industry in Turkey; people consider making movies and TV shows as a hobby of the rich. People have general ideas for employees in this sector, namely that men are successful and productive; women are simply referred to by their identities in front of the screen. This study is also a preliminary research for issues addressed by the so-called second-wave feminism regarding different classes of women such as Turkish, Kurdish, Alawite, lesbian, bisexual in Turkish film industry. 


\section{References}

Bem, Sandra. 1983. Gender Schema Theory and Its Implications for Child Development: Raising Gender-Aschematic Children in a Gender-Schematic Society. Signs vol. 8: 598-616.

Blackstone, Amy. 2003. Gender Roles and Society. The University of Maine: Digital Commons@UMaine.

Boyce, Carolyn and Palena Neale. 2006. Conducting In-Depth Interviews: A Guide for Designing and Conducting In-Depth-Interviews for Evaluation Input. Watertown: Pathfinder International.

Cleveland, Jeanette N. and Melinda E. Kerst. 1993. Sexual Harassment and Perceptions of Power: An Under-Articulated Relationship. Journal of Vocational Behavior vol. 42, no. 1: 49-67.

Department of General Directorate on the Status and Problems of Women, Republic of Turkey Prime Ministry. 2004. Response of the Republic Of Turkey to the Questionnaire on Implementation of the Beijing Platform for Action. Ankara.

Doğramacı, Emel. 1992. Türkiye'de Kadının Dünü ve Bugünü [Women’s Past and Present in Turkey]. İstanbul: Türkiye İş Bankası Yayınları.

Donovan, Josephine. 2000 [1985]. Feminist Teory: The Intellectual Traditions. New York, London: Continuum.

Dökmen, Zehra. 2004. Toplumsal Cinsiyet: Sosyal Psikolojik Açıklamalar [Gender: Socio- Psychological Disclosures]. Ankara: Sistem Yayıncılık.

Erus, Zeynep Ç. and Hasan Gürkan. 2012. Toplumsal Cinsiyet ve Sinemaya Yansıması: Yeniden Çekimler Aracılığıyla Japon ve Amerikan Sinemalarında Kadının Temsiline Bir Bakış [Gender and its Reflection on Cinema: A Look at the Representation of Women in Japanese and American Cinemas through Reflections]. Selçuk Communication Journal vol. 7, no. 3: 206-217.

European Women's Audiovisual Network Reports 2006-2013. http://www. ewawomen.com/uploads/files/MERGED_Press-2016.pdf. Last accessed 12. 01. 2019.

Fausto-Sterling, Anne. 1993. Myths of Gender: Biological Theories about Women and Men. New York: Basic Books.

Fausto-Sterling, Anne. 2012. Sex/Gender: Biology in a Social World. New York: Routledge.

Gentile, Douglas. 1993. Just What Are Sex and Gender, Anyway? A Call for a New Terminological Standard. Psychological Science vol. 4, no. 2: 120-122. 
Gutek, Barbara. A. 1989. Sexuality in the Workplace: Key Issues in Social Research and Organizational Practice. In The Sexuality of Organization, eds. J. Hearn, D. L. Sheppard, P. Tancred-Sheriff, and G. Burrell, 56-70. London: Sage Ltd.

Hausmann, Ricardo, Laura D. Tyson, and Saadia Zahidi. 2010. The Global Gender Gap Report. Geneva: World Economic Forum.

Hymowitz, Carol and Timothy D. Schellhardt. 1986. The Glass Ceiling: Why Women Can't Seem to Break the Invisible Barrier that Blocks them from the Top Jobs. The Wall Street Journal, 24 March: 1.

Inter-Agency Standing Committee. 2009. IASC Policy Statement Gender Equality in Humanitarian Action. http://www.humanitarianinfo.org. Last accessed 17. 10. 2017.

Jackson, Robert and Meredith Newman. 2004. Sexual Harassment in the Federal Workplace Revisited: Influences on Sexual Harassment. Public Administration Review vol. 64, no. 6: 705-717.

Kammeyer, Kenneth, George Ritzer, and Norman Yetman. 1997. Sociology: Experiencing Changing Societies. Boston: Allyn \& Bacon.

Kaypakoğlu, Serdar. 2004. Toplumsal Cinsiyet ve Medya: Medyada Cinsiyet Stereotipleri [Gender and Media: Gender Stereotypes in the Media]. İstanbul: Naos Yay.

Kazgan, Gülten. 1979. Türk Ekonomisinde Kadınların İşgücüne Katılması, Mesleki Dağılımı, Eğitim Düzeyi [Female Labor Force Participation, Professional Distribution, Educational Level and Socio-Economic Level]. In Sosyo-Ekonomik Düzeyi. Türkiye'de Kadın [Turkish Economy. Women in Turkey], 155-189. Ankara: Türk Sosyal Bilimler Derneği.

Kocacik, Faruk and Veda B. Gökkaya. 2005. Türkiye’de Çalışan Kadınlar ve Sorunlar [Working Women and Problems in Turkey]. C.Ü. Journal of Economics and Administrative Sciences vol. 6, no. 1: 195-219.

Köse, Erdoğan 2013. Women Education in Turkey: A Meta Analysis Study. International Journal of Humanities and Social Science vol. 3, (Special Issue April): 98-105.

Lips, Hilary. 1998. Sex \& Gender: An Introduction. California: Mayfield.

Marshall, Gordon. 1999. Sosyoloji Sözlüğü [Sociology Dictionary]. Ankara: Bilim ve Sanat Yay.

Mayers, David. 1996. Social Psychology. New York: McGraw-Hill.

Oakley, Ann. 1972. Sex, Gender and Society. London: Temple Smith. 
Öztürk-Akar, Ebru. 2012. Motivations of Turkish Pre-service Teachers to Choose Teaching as a Career. Australian Journal of Teacher Education vol. 37, no. 10: 67-84

Rice, Willy. 1996. Race, Gender, 'Redlining,' and the Discriminatory Access to Loans, Credit, and Insurance: An Historical and Empirical Analysis of Consumers Who Sued Lenders and Insurers in Federal and State Courts, 19501995. San Diego Law Review vol. 33. https://ssrn.com/abstract=2892349. Last accessed 12. 01. 2019.

Rubin, Gayle. 1975. The Traffic in Women: Notes on the Political Economy of Sex. New York: Monthly View Press.

Seger, Linda 2003. When Women Call the Shots: The Developing Power and Influence of Women in Television and Film. Lincoln, NE: iUniverse Publishing. Tanrı̈̈ver, Hülya T. 2000. Medya sektöründe kadın işgücü. Toplum ve Bilim [Women's Labor Force in the Media Sector]. Birikim Publishing Güz [Society and Science. Fall]: 86.

Turkish Statistical Institute. 2015. Turkey in Statistics. http://www.tuik.gov.tr. Last accessed 12. 01. 2019.

Uggen, Christopher and Amy Blackstone. 2004. Sexual Harassment as a Gendered Expression of Power. American Sociological Review no. 69: 64-92.

Unger, Rhoda and Mary Crawford. 1993. Sex and Gender - the Troubled Relationship between Terms and Concepts. Psychological Science vol. 4, no. 2: $122-124$.

U.S. Glass Ceiling Commission 1995. Good for Business: Making Full Use of the Nation's Human Capital. Washington: Government Printing Office. http:// digitalcommons.ilr.cornell.edu/key_workplace/116/. Last accessed 12. 01. 2019.

Zanden, James. 1990. Sociology. McGraw-Hill. 